\begin{tabular}{|l|l|l|l|}
\hline Eiszeitalter u. Gegenwart & 35 & $\begin{array}{c}109-118 \\
3 \text { fig., 2 tab. }\end{array}$ & Hannover 1985 \\
\hline
\end{tabular}

\title{
A Major Coastal Flood During the Holocene in Eastern Scotland
}

\author{
David E. Smith, Robin A. Cullingford \& B. Andrew Haggart *)
}

Storm surge, main postglacial transgression, sections, paleoenvironmental context, sand layer, cliff, C14 dating, Holocene.

Eastern Scotland, North Sea

\begin{abstract}
A b s t r a c t: At a number of locations on the east coast of Scotland, raised Holocene estuarine deposits belonging to the Main Postglacial Transgression contain a distinctive layer predominantly of grey micaceous silty fine sand. Where the deposits reach into former coastal peat mosses at their landward margins, they form tapering wedges of sediment within the peat, and here the grey micaceous silty fine sand also occurs as a tapering wedge of sediment. Diatom analyses indicate that it is of marine origin; pollen analyses indicate that it is associated with early to middle Flandrian assemblages; and ${ }^{14} \mathrm{C}$ analyses of peat at the upper and lower contacts indicate an event of relatively short duration around $7000 \mathrm{~B}$. P. It is thought at present that the layer resulted from either an increase in the rate of rise of relative sea level or a storm surge of unusual magnitude.
\end{abstract}

\section{[Eine bedeutende Küsten-Überflutung im östlichen Schottland während des Holozän]}

$\mathrm{Kurzf}$ assung: Gehobene holozäne ästuarine Ablagerungen der postglazialen Haupttransgression enthalten in einer Anzahl von Fundpunkten an der Ostküste Schottlands eine charakteristische Schicht vorwiegend aus grauem, glimmerführendem Feinsand. Dort wo die Sedimente sich landseitig mit den ehemaligen Küstenmooren verzahnen, bilden sie im Torf spitz auslaufende Lagen, und auch hier tritt der graue, glimmerführende Feinsand als spitzer Sedimentkeil auf. Diatomeenanalysen deuten auf einen marinen Ursprung hin, Pollenanalysen zeigen eine früh- bis mittelatlantische Florenvergesellschaftung an und ${ }^{14} \mathrm{C}$-Analysen von Torf aus dem oberen und unteren Kontakt deuten auf ein Ereignis von relativ kurzer Dauer um 7000 v. h. Gegenwärtig wird angenommen, daß die Lage entweder auf eine kurzfristig erhöhte Rate des relativen Meeresspiegel-Anstiegs oder auf eine Sturmflut ungewöhnlichen Ausmaßes zurückzuführen ist.

*) Addresses of the authors: Dr. D. E. SмIтH, Department of Geography, Coventry (Lanchester) Polytechnic, Coventry CV1 5FB, U.K.

Dr. R. A. Culungrord, Department of Geography, Exeter University, Amory Building, Rennes Drive, Exeter EX 4, 4RJ, Devon, U.K.

Dr. B. A. Haggart, Geography Section, City of London Polytechnic, Calcutta House Precinct, Old Castle Street, London, El 7 NT, U.K. 
Since the early 1960s, Holocene relative sea-level changes in eastern Scotland have been studied in increasing detail. Curves of relative sealevel changes have been produced for the western Forth valley (SIssons \& BROOKS 1971) and lower Strathearn (CuLLINGFord et al. 1980) and very detailed information is now available on the distribution, altitude, stratigraphical context and age of displaced shorelines over about one third of the coastline (GRAY 1983). The main event recorded, the Main Postglacial Transgression (Sissons 1974), is marked by widespread marine and estuarine deposits burying peat which had formed earlier upon lower surfaces. The earliest reliable date so far obtained from the transgressive contact is $8320 \pm 57{ }^{14} \mathrm{C}$ years B.P. (HARKNESS \& WIISON 1975) and the subsequent culmination has been dated at various sites at between $7480 \pm 125$ and $5700 \pm 90{ }^{14} \mathrm{C}$ years B. P. (SмITH et al. 1983). Residual glacioisostatic uplift has raised the deposits above present sea levels over much of the area, and several former shorelines have been identified. The highest of these, associated with the maximum of the transgression, is the Main Postglacial Shoreline (SISsons et al.

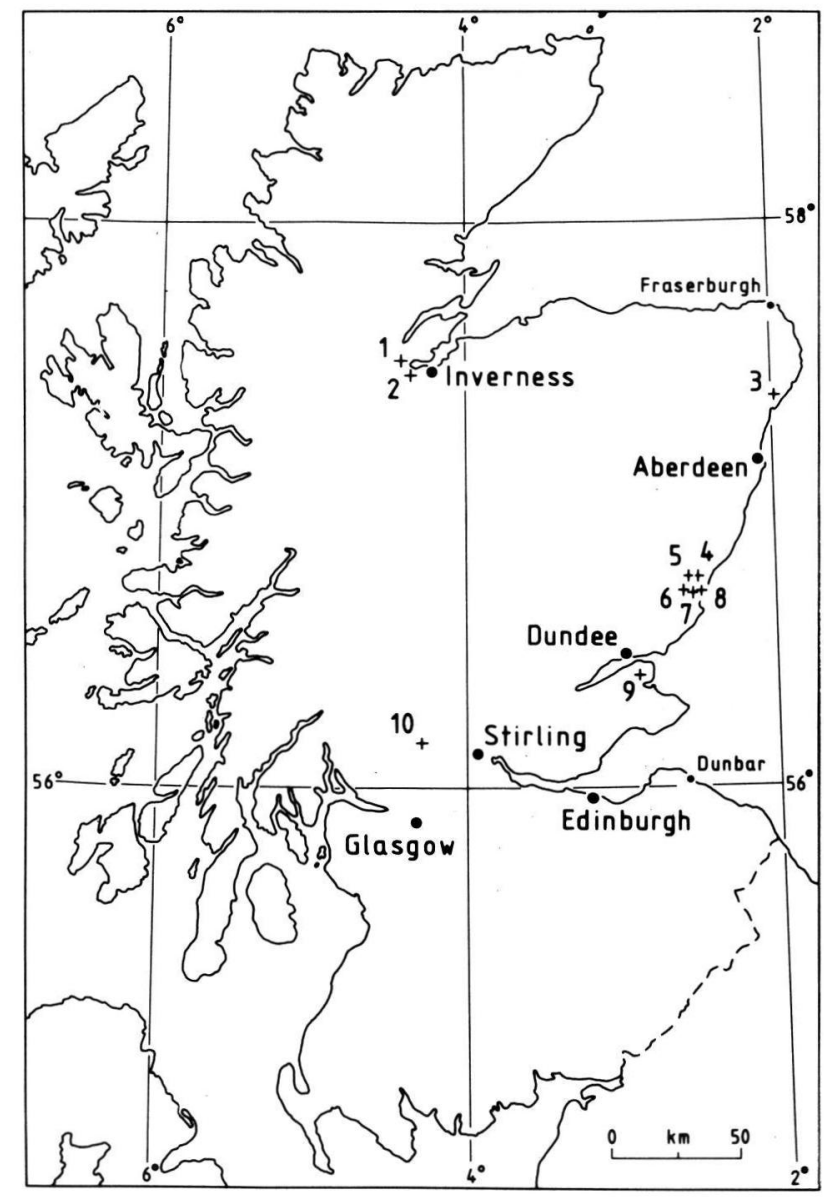

Fig. 1: Location of sites: 1. Barnyards; 2. Moniack; 3. Waterside; 4. Dubton; 5. Puggieston; 6. Bonnyton; 7. Old Montrose; 8. Fullerton; 9. Silver Moss; 10. Easter Offerance. 
Tab. 1: Altitudinal relationships and thickness of the grey micaceous silty fine sand layers

\begin{tabular}{|c|c|c|c|c|c|}
\hline $\begin{array}{l}\text { Site } \\
\text { No. }\end{array}$ & Name & $\begin{array}{l}\text { Altitude of base } \\
\text { of layer } \\
\text { (m, O.D.) } \\
\text { at inland limit }\end{array}$ & $\begin{array}{l}\text { Altitudinal range } \\
\text { (m, O.D.) } \\
\text { of base } \\
\text { of layer }\end{array}$ & $\begin{array}{l}\text { Maximum altitude } \\
\text { of Main Postglacial } \\
\text { shoreline near site } \\
\text { (m, O.D.) }\end{array}$ & $\begin{array}{l}\text { Maximum } \\
\text { Thickness } \\
\text { of layer } \\
\text { (m) }\end{array}$ \\
\hline 1 & Barnyards & 8.61 & $3.65-8.61$ & 9.65 & 0.70 \\
\hline 2 & Moniack & 9.95 & $5.95-9.95$ & 9.65 & 0.43 \\
\hline 3 & Waterside & 2.40 & $0.10-2.40$ & 4.15 & 0.04 \\
\hline 4 & Dubton & 6.70 & $3.96-6.70$ & 6.11 & 0.40 \\
\hline 5 & Puggieston & 5.59 & $4.25-5.59$ & 5.96 & 0.23 \\
\hline 6 & Bonnyton & 6.17 & $4.82-6.17$ & 6.65 & 0.02 \\
\hline 7 & Old Montrose & 5.55 & $4.71-5.55$ & 5.87 & 0.18 \\
\hline 8 & Fullerton & 7.88 & $3.87-8.30$ & 7.98 & 0.26 \\
\hline 9 & Silver Moss & 8.44 & $4.28-8.44$ & 8.43 & 0.17 \\
\hline 10 & Easter Offerance & $11.19+$ & not known & 14.35 & 0.06 \\
\hline
\end{tabular}

1966), and up to five lower shorelines formed during the subsequent regression are found below this in some former estuarine areas (SMITH 1968; CulLINGFORD 1972). In areas towards the margins of the glacio-isostatically affected area, the deposits of later sea levels cover the Main Postglacial Shoreline (SMITH et al. 1983), but over much of the coastal landscape of eastern Scotland, the Main Postglacial Shoreline is visible and the deposits associated with the Main Postglacial Transgression are widespread, notably the raised estuarine sediments of the carselands.

In a number of recent studies of the stratigraphy of deposits associated with the culmination of the Main Postglacial Transgression, a prominent layer, predominantly of grey micaceous silty fine sand has been identified within the deposits at several locations in eastern Scotland. Such a layer was first recorded in the western Forth valley by SISSONS \& SMITH in 1965, and at that time, on the basis of stratigraphy alone, was interpreted as having been laid down following a flood of the river Forth. Subsequently, a similar layer has been identified by the authors and others in accounts of the Montrose (SMith et al. 1980), East Fife (ChISHOlm 1971; Haggart 1978; Morrison et al. 1981), Beauly Firth (HAGGART 1982) and Ythan estuary (SMITH et al. 1983) areas, whilst further work in the western Forth valley has confirmed its extent there $\mathrm{J}$. B. Sissons pers. comm.). It seems likely therefore, that if the layer is of the same age at each location, a local origin is unlikely and a widespread event of some significance may be indicated. 


\section{Stratigraphical and Palaeoenvironmental Context of the Sand layer}

The sites where the layer has been identified are shown in Figure 1 and details of the altitude and thickness of the layer at each site are given in Table 1. Stratigraphically, all the sites studied are remarkably similar. Raised estuarine deposits of grey silty clay ("carse clay"), relating to the Main Postglacial Shoreline, penetrate small peat mosses inland and within these mosses form wedges of sediment. Within the grey silty clay to seaward a distinctive layer of grey micaceous silty fine sand occurs and within the peat to landward this forms a separate wedge below the wedge of grey silty clay. Figure 2 shows the stratigraphical relationship of the deposits at site 8, which is typical of all the sites except site 6 , where the grey micaceous silty fine sand occurs only intermittently within the grey silty clay. Figure 3 shows the appearance of the layer at a cliff exposure near site 8 . At all sites the grey micaceous silty fine sand layer contrasts markedly with the surrounding deposits, being clearly visible in both open sections and in cores. Although not proved more than $70 \mathrm{~cm}$ and generally less than $15 \mathrm{~cm}$ in thickness, it has been located in over 100 boreholes and is locally remarkably persistent. For example, beneath the carseland surface around the Montrose Basin (sites 4-8), it probably covers an area in excess of $5 \mathrm{~km}^{2}$. The layer is almost unique in the carseland deposits. In over 800 boreholes put down by the writers in these sediments the few other sand layers located are normally associated with river channels and are very restricted in extent. Only in the Carse of Gowrie has a similarly widespread sand layer been found (Cullingford 1972), and this is thicker, shelly and was probably formed earlier in the Main Postglacial Transgression than the sand layer under discussion.

At most sites no structures have been observed in the layer described here, though at site 2 , it fines upwards to a clay-silt towards its landward limit. Particle size analysis has so far been carried out at two sites. In East Fife, a gully adjacent to that at site 9 contains an identical stratigraphy. $150 \mathrm{~m}$ from its landward limit it contains $93.5 \%$

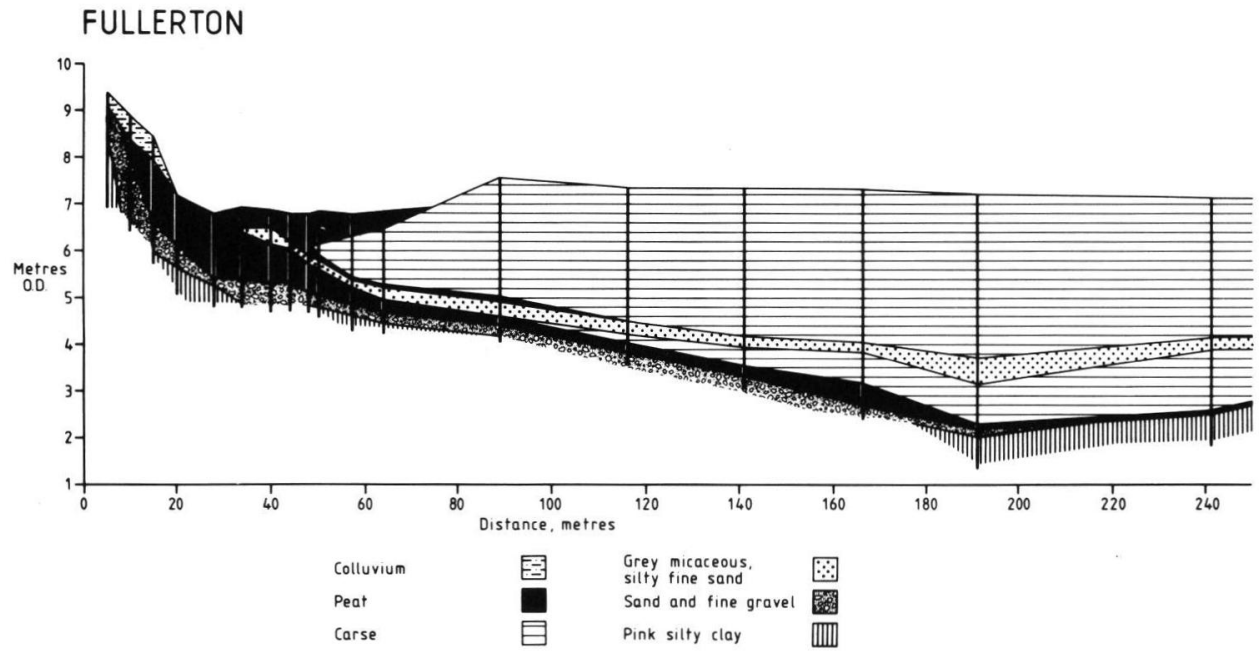

Fig. 2: Section through the deposits at Fullerton (site 8) showing the position of the sand layer. 


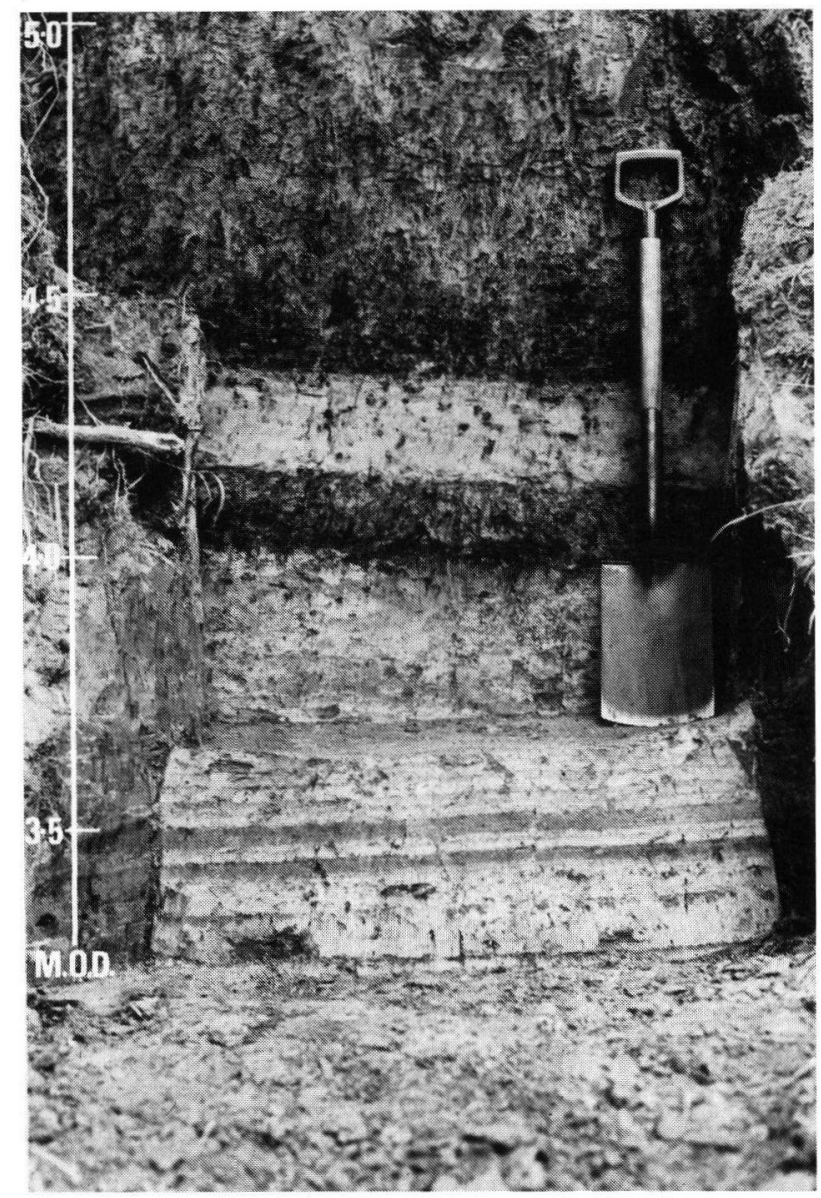

Fig. 3: Photograph of a cliff section showing the layer at Maryton, near site 8 .

The scale shows altitudes above Ordnance Datum (O.D.). At the base of the section laminated Late Devensian clays reach $4.00 \mathrm{~m}$., O. D.: above these lies peat at $4.00-4.15$; the grey micaceous silty fine sand layer at $4.15-4.33$; silty peat at $4.33-4.43$; and grey silty clay ("case clay") at 4.43 to the surface at 6.80 .

sand, $5.5 \%$ silt and $1 \%$ clay (HAGGART 1978). In the Beauly Firth at site 1 , the basal $5 \mathrm{~cm}$ of the layer close to its landward limit contains $21 \%$ gravel, $54.5 \%$ sand, $21 \%$ silt and $3 \%$ clay, whilst the upper $5 \mathrm{~cm}$ contains $8 \%$ gravel, $61.5 \%$ sand, $22.5 \%$ silt and $8 \%$ clay.

Diatom analysis of the layer at two sites $(2,10)$ supports a marine origin. At site 2 , the layer is characterised by a number of species of marine diatoms, amongst which Paralia sulcata (EHRENBERG) CLEVE, Cocconeis scutellum and Grammatophora oceanica var. macilenta are the most abundant. At site 10, M. RoBinson (pers. comm.) found only low diatom sums, with mostly eroded centric diatoms. Paralia sulcata (EHRENBERG) Cleve was most abundant, reaching $38 \%$ of the diatom sum in one level with Hyalodiscus stellinger, Diploneis spp. and Nitzschia navicularis well represented. Although 
some brackish-marine diatoms are present at both sites, the overall indication is of predominantly marine assemblages.

Pollen analysis carried out across the sequences of deposits at all sites except $4-7$ indicates that the layer is associated with early to middle Flandrian assemblages. There is little indication of major changes or of marked lacunae in the sequences. At sites 1, 2 and 9 some evidence of peat erosion at the base of the layer is found, and a local pollen assemblage zone boundary has been identified in the layer in each diagram. At site 10, there is some indication of salt marsh vegetation in association with the layer $(\mathrm{C}$. L. BROOKS, pers. comm.). At all other sites however, no changes in pollen assemblages are associated with the layer and no marked lacunae are indicated. Thus the deposition of the layer does not appear to have markedly influenced the pollen spectrum, unlike the grey silty clay which, even when relatively thin (e.g. $0.77 \mathrm{~m}$ at site 8 ) is associated with significant changes in pollen (SMITH et al. 1980, 1983; MORRISON et al. 1981).

\section{Age of the sand layer}

Radiocarbon dates on peat containing the layer were reported in the studies quoted above from sites $2,3,8,9$ and 10 and additional dates have recently been obtained from site 5 (Table 2). At sites, 5, 8 and 10 peat from both upper and lower contacts with the layer has been dated, whilst at site 2 , dates have been obtained from the lower contact and $2 \mathrm{~cm}$ above the upper contact. At site 10, only peat from the lower contact has been dated and at site 3 a composite date from samples at both upper and lower contacts has been obtained. All peat samples were $2 \mathrm{~cm}$ thick except those at site $9(1 \mathrm{~cm})$ and at site $2(5 \mathrm{~cm})$. The dates range between $7555 \pm 110$ and $6850 \pm 140{ }^{14} \mathrm{C}$ years, B. P., broadly supporting the pollen evidence for the age of the layer. In detail, the dates are relatively consistent. The dates for the age of the basal contact range from $7555 \pm 110$ to $6870 \pm 50{ }^{14} \mathrm{C}$ years B. P., but the two oldest dates are reportedly from surfaces showing possible evidence of erosion (MORRISON et al. 1981; HAGGART 1982), and if these are ignored the range becomes $7140 \pm 120$ to $6870 \pm 50{ }^{14} \mathrm{C}$ years $\mathrm{B}$. P., dates which overlap at $2 \sigma$. There does not seem to be much regional variation in the dates, although those from the Beauly Firth are slightly older. However, the more acceptable upper peat date at site 2 , in that area, still lies within $2 \sigma$ of two of the three upper contact dates (those at sites 8 and 9). The radiocarbon evidence is not unequivocal, but it does seem more likely that a relatively short-lived event which took place around $7000{ }^{14} \mathrm{C}$ years B. P. is indicated.

\section{Origin of the sand layer}

The stratigraphical, microfossil and radiocarbon evidence cited above presents a reasonably coherent picture. The distribution of the layer and its diatom content indicate that it is of marine origin. The stratigraphy and radiocarbon dates support the concept of a single event, whilst the pollen and radiocarbon dates indicate an event of relatively short duration. The period of time involved could range from a few days to several hundred years. The widespread distribution of the layer, and the variety of locations in which it is found probably rule out local origins, such as the breaching of barrier systems. Two possible types of event seem to be indicated: a temporary increase in the 
Tab. 2: Radiocarbon dates from peat above and below grey micaceous silty fine sand layers

\begin{tabular}{|c|c|c|c|c|c|c|}
\hline $\begin{array}{l}\text { Site } \\
\text { No. }\end{array}$ & Location & $\begin{array}{l}\text { National Grid } \\
\text { Reference }\end{array}$ & Details of Sample & $\begin{array}{l}\text { Altitude at Contact } \\
\text { (m, O.D.) }\end{array}$ & $\begin{array}{l}{ }^{14} \mathrm{C} \text { age } \\
\text { yr B.P. }\end{array}$ & Lab. Ref. \\
\hline \multirow[t]{2}{*}{2} & Moniack & NH 5421.4393 & $\begin{array}{l}\text { Basal } 5 \mathrm{~cm} \text { of monocotyledonous peat } \\
\text { with Phragmites rhizomes, above layer }\end{array}$ & 7.28 & $7270 \pm 90$ & BIR-1126 \\
\hline & & & $\begin{array}{l}\text { Top } 5 \mathrm{~cm} \text { of humified peat, some } \\
\text { Phragmites remains, below layer }\end{array}$ & 6.87 & $7430 \pm 170$ & BIR-1127 \\
\hline 3 & Waterside & NK 0067.2666 & $\begin{array}{l}\text { Composite of } 2 \mathrm{~cm} \text {-thick layers } \\
\text { of peat above and below the layer }\end{array}$ & $\begin{array}{l}2.51 \text { (upper contact) } \\
2.48 \text { (lower contact) }\end{array}$ & $6850 \pm 140$ & SRR-1565 \\
\hline \multirow[t]{2}{*}{5} & Puggieston & NO 6975.6034 & $\begin{array}{l}\text { Basal } 2 \mathrm{~cm} \text { of humified peat } \\
\text { above layer }\end{array}$ & 4.88 & $6850 \pm 75$ & SRR-2119 \\
\hline & & & $\begin{array}{l}\text { Top } 2 \mathrm{~cm} \text { of Phragmites-Carex peat } \\
\text { below water }\end{array}$ & 4.73 & $7120 \pm 75$ & SRR-2120 \\
\hline \multirow[t]{2}{*}{8} & Fullerton & NO 6748.5605 & Basal $2 \mathrm{~cm}$ of Carex peat above layer & 5.50 & $6880 \pm 110$ & BIR-867 \\
\hline & & & Top $2 \mathrm{~cm}$ of Carex peat below layer & 5.32 & $7140 \pm 120$ & BIR-823 \\
\hline \multirow[t]{2}{*}{9} & Silver Moss & NO 4538.2348 & $\begin{array}{l}\text { Basal } 1 \mathrm{~cm} \text { of monocotyledonous } \\
\text { peat, above layer }\end{array}$ & 6.38 & $7050 \pm 100$ & SRR-1333 \\
\hline & & & Top $1 \mathrm{~cm}$ of Carex peat, below layer & 6.20 & $7555 \pm 110$ & SRR-1334 \\
\hline 10 & Easter Offerance & NS 5766.9622 & Top $2 \mathrm{~cm}$ of peat, below layer & . $\quad 11.19$ & $6870 \pm 50$ & SRR-1603 \\
\hline
\end{tabular}


rate of relative sea level rise, lasting up to a few hundred years, or a much shorter storm event, such as a North Sea storm surge.

The possibility that the sand layer resulted from an increase in the rate of relative sea-level rise can be supported by analogy with other areas. Farther south in Britain away from areas of significant isostatic uplift, fluctuations in the rise of Holocene sea levels have been identified at a number of locations. It may have been that a relatively rapid, eustatic based fluctuation is recorded here. The occurrence of the layer in very sheltered locations such as that at site 10 may support this origin. However, its marked difference to the rest of the marine deposit in which it occurs is puzzling if it did originate in this way.

A storm origin is supported by three factors. Firstly, the fairly coarse nature of the layer in its stratigraphical context is suggestive of a relatively high energy environment of deposition. Secondly, the abundance of Paralia sulcata (EHRENBERG) Cieve in the deposit is supportive of a storm event, since Paralia sulcata, a tychopelagic form, is especially common in coastal plankton after gales (HeNDEY 1964). Thirdly, at all sites except 1 and 3 it extends farther inland than the culminating deposit of the Main Postglacial Transgression, whilst at sites in narrow embayments $(2,4-9)$, it reaches close to and sometimes actually exceeds the height of that deposit and of the Main Postglacial Shoreline in the locality (see Table 1 and Figure 2). This suggests particularly strong tidal effects, such as might be associated with a storm event.

The evidence at present probably marginally favours storm origin, particularly in view of the coarseness of the layer in contrast to the remainder of the carseland deposits. Since no similar layer appears to have been found in analagous areas in western Scotland (cf. JARDINE 1975), a North Sea storm surge is indicated. Such an explanation seems at first sight unsatisfactory in view of the uniqueness of the layer. Many storm surges have been recorded around the shores of the North Sea in historic times (GoTTSCHALK 1971, 1975, 1977), and by analogy a number must also have occurred during the perhaps 2000 years of the Main Postglacial Transgression, although it has been suggested that the frequency of such events may have varied during the Holocene (LINKE 1981). However, a recent study in South East Scotland (Smith, Cullingford, Harkness \& DAwSON, 1985) has shown that in the period immediately prior to the deposition of the layer, relative sea level was rising rapidly, but that it subsequently slowed markedly. It may have been that a major storm surge during the period of rapidly rising relative sea level widely inundated low-lying coastal areas, but that the subsequent slowing down of the rise prevented later surges from being so effective.

\section{Acknowledgements}

We should like to thank Drs. J. B. Sissons, M. RoBinson and C. L. Brooks for permission to cite unpublished work relating to their Eastern Offerance site; Dr. C. R. FIRTH for permission to cite unpublished height information for the Main Postglacial Shoreline in the Beauly Firth area; and N.E. R. C., the University of Birmingham, Dr. D.D. Harkness and Dr. R.E. G. Williams for ${ }^{14} \mathrm{C}$ assays. Dr. B. A. HaGgarT thanks N.E.R. C. for the award of a Research Studentship and Dr. M. J. Tooley for advice and encouragement during his tenure of that studentship at Durham University. Mrs. S. ADDLETON drew the map and diagram for this paper. 


\section{References}

Chisholm, J. I. (1971): The stratigraphy of the post-glacial marine transgression in N.E. Fife. — Bull. Geol. Surv. Gt. Br., 37: 91-107; London.

Culungrord, R. A. (1972): Lateglacial and Postglacial shoreline displacement in the Earn-Tay area and Eastern Fife. - Ph. D. thesis, University of Edinburgh; Edinburgh. - [Unpubl.].

-, Caseldine, C. J. \& Gotts, P. E. (1980): Early Flandrian land and sea-level changes in Lower Strathearn. - Nature, 284, 159-161; London.

GotTschalk, M. K. E. (1971, 1975, 1977): Stormuloeden en Riveroverstromingers in Nederland, 6000-1700 A. D. - 3 Vols. Van Gorcum; Essen.

GrAY, J. M. (1983): The measurement of shoreline altitudes in areas affected by glacio-isostasy, with particular reference to Scotland. - In: Shorelines and Isostasy (SмITH, D. E. and Dawson, A. G. eds.) 97-127: London, New York (Academic Press).

HaGgart. B. A. (1978): A Pollen and Stratigraphical Investigation into a Peat Deposit in St. Michael's Wood, near Leuchars, Fife. - M. A. Thesis, University of St. Andrews: 54 pp.; St. Andrews. - [Unpubl.].

- (1982): Flandrian sea-level changes in the Moray Firth area. Ph. D. Thesis, University of Durham: 371 pp.; Durham.

Harkness, D. D. \& Wilson, H. W. (1974): Scottish Universities Research and Reactor Centre radiocarbon measurements II. - Radiocarbon, 16: 238-251; New Haven.

Hendey, N. I. (1974): An introductory account of the smaller algae of British coastal waters. Part V: Bacillariophyceae (Diatoms). - Her Majesty's Stationery Office, London: 317 pp.; London.

JARDINE, W. G. (1975): Chronology of Holocene Marine Transgression and regression in southwestern Scotland. - Boreas, 4: 173-196; Oslo.

LiNKE, G. (1981): Ergebnisse und Aspekte zur Klimaentwicklung im Holozän. — Geol. Rdsch., 70: 774-783; Stuttgart.

Morrison, J., Smith, D. E., Culuingford, R. A. \& Jones, R. L. (1981): The culmination of the Main Postglacial Transgression in the Firth of Tay area, Scotland. - Proc. Geol. Ass., 92 (3): 197-209; London.

Sissons, J. B. (1974): The Quaternary in Scotland: a review. — Scott. J. Geol., 10: 311-337; Edinburgh.

- \& Sмiтh, D. E. (1965): Peat bogs in a Post-glacial sea and a buried raised beach in the western part of the Carse of Stirling. - Scott. J. Geol., 1: 247-255; Edinburgh.

- \& Brooks, C. L. (1971): Dating of early postglacial land and sea level changes in the western Forth Valley. - Nature Phys. Sci., 234: 124-127; London.

-, Sмith, D. E. \& Culungrord, R. A. (1966): Lateglacial and postglacial shorelines in southeast Scotland. - Trans. Inst. Br. Geogr., 39: 9-18; London.

Sмiтн, D. E. (1968): Post-glacial displaced shorelines in the surface of the carse clay on the north bank of the river Forth, in Scotland. - Z. Geomorph. 12: 388-408; Berlin, Stuttgart. 
Smith, D. E., Culdingford, R. A. \& Seymour, W. P. (1982): Flandrian relative sea-level changes in the Philorth valley, north-east Scotland. - Trans. Inst. Br. Geogr. N. S., 7: 321-336; London.

- , - - \& Brooks, C. L. (1983): Flandrian relative sea-level changes in the Ythan valley, Northeast Scotland. - Earth Surface Processes and Landforms, 8: 423-438; London.

-, - - Harkness, D. D. \& Dawson, A. G. (1985): The stratigraphy of Flandrian relative sealevel changes at a site in Tayside, Scotland. - Earth Surface Processes and Landforms, 10: 17-25; London. - [In press].

-, Morrison, J., Jones, R. L. \& Culuingford, R. A. (1980): Dating the Main Postglacial Shoreline in the Montrose area, Scotland. In: Cullingford, R. A., Davidson, D. A. \& Lewin, J. eds. Timescales in Geomorphology: 225-245; (Wiley) Chichester.

Manuscript accepted on 15.10. 1984 